\title{
The antinociceptive role of central arginine vasopressin is involved in the endogenous opiate peptide, serotonin and acetylcholine systems
}

\author{
Xiang-Yong Li ${ }^{1,2}$, Jun Yang ${ }^{1 *}$, Xi-Qing Yan ${ }^{1}$, Yan-Juan Pan ${ }^{1}$, Ying Zhao ${ }^{1}$, Pei-Yong Qiu ${ }^{1}$, Xi-Jian Zhou ${ }^{2}$, \\ Da-Xin Wang ${ }^{3}$
}

${ }^{1}$ College of Pharmacy, Xinxiang Medical University, Xinxiang, Henan, China;

${ }^{2} 101$ Hospital of PLA, Wuxi, Jiangsu, China;

${ }^{3}$ Jiangsu Su Bei People's Hospital, Yangzhou University, Yangzhou, Jiangsu, China.

Email: ${ }^{*}$ bcd2009@126.com

Received 19 August 2011; revised 5 October 2011; accepted 24 October 2011.

\begin{abstract}
Our previous work has demonstrated that arginine vasopressin (AVP) plays a role in pain modulation. The present study investigated which kinds of neuropeptides and neurotransmitters in central nervous system might be involved in AVP antinociceptive role in the rat. The results showed that (1) intraventricular injection (icv) of $\mathrm{V}_{1}$ receptor antagonist $\left[\mathrm{d}\left(\mathrm{CH}_{2}\right)_{5}\right.$ $\operatorname{Tyr}(\mathrm{Me}) \mathrm{AVP}]$ and $\mathrm{V}_{2}$ receptor antagonist $\left[\mathrm{d}\left(\mathrm{CH}_{2}\right)_{5}\right.$ $\left.\left[\mathrm{D}-\mathrm{Ile}^{2}, \mathrm{Ile}^{4}, \mathrm{Ala}^{9}-\mathrm{NH}_{2}\right] \mathrm{AVP}\right]$ blocked the antinociceptive effect induced by AVP (icv), (2) the opiate recaptor antagonist (naloxone) reversed the antinociceptive effect induced by AVP (icv), and (3) both the serotonin receptor antagonist (cypoheptadine) and $M$ receptor antagonist (atropine) could attenuate the antinociceptive effect induced by AVP (icv); but (4) oxytocin, dopamine, N-methyl-D-aspartate (NMDA), $\gamma$-aminobutyric acid (GABA), $N, \alpha$ or $\beta$ receptor antagonist did not influence the antinociceptive effect induced by AVP (icv). The data suggested that AVP antinociceptive role was involved in the endogenous opiate peptide, serotonin and acetylcholine systems in central nervous system.
\end{abstract}

Keywords: Arginine Vasopressin; Antinociception; Endorgenous Opiate Peptide; Serotonin; Acetycholine

\section{INTRODUCTION}

Arginine vasopressin (AVP), a nonapeptide posterior pituitary hormone, is synthesized in the paraventricular and supraoptic nuclei of hypothalamus [1]. This hormone, combined with an apparent carrier protein (neurophysin), is transported along the hypothalamo-hypophyseal pathway to the neurohypophysis, where it is stored for subsequent release [2]. The remarkable functions of AVP include body fluid homeostasis, hormone probation, cardiovascular control, learning and memory [3]. Many studies have showed that AVP influences antinociception in both human and nonhuman species [1,4-7]. Intraventricular injection (icv) of AVP increases the pain threshold, while anti-AVP serum (icv) decreases the pain threshold, but intrathecal injection (ith) or intravenous injection (iv) of either AVP or anti-AVP serum does not influence the pain threshold $[8,9]$. Pain stimulation could change AVP concentration in some brain nuclei, but did not change AVP concentration in the spinal cord and serum $[8,9]$. The antinociceptive effect of AVP is limited to the brain nuclei, not the spinal cord and peripheral organs.

Many studies have proven that most of neuropeptides (such as endogenous opiate peptides) and neurotransmitters (such as serotonin, acetylcholine, norepinephine and epinephrine) are involved in pain modulation [10]. For example, oxytocin (icv) could increase the pain threshold and enhance acupuncture analgesia, while anti-oxytocin serum (icv) decreases the pain threshold and weakens acupuncture analgesia [11-13]. However, it is not clear the interaction between AVP and other neuropeptides or neurotransmitters in pain modulation. The present study investigated which neuropeptides and neurotransmitters in central nerve system might be involved in AVP antinociceptive effect in the rat.

\section{MATERIALS AND METHODS}

\subsection{Animals}

Adult male Sprague-Dawley rats weighing 180-220 g, which were obtained from Animal Center of Yangzhou University, Yangzhou, Jiangsu, China, were housed with food and water available ad libitum in a colony room under controlled temperature, humidity and a 12 hours 
light/dark cycle (light at 6:00 AM and dark at 6:00 PM). All the procedures were approved by Animal Care Committee of Yangzhou University and conducted according to the guidelines of the International Association for the Study of Pain [14].

\subsection{Materials}

AVP, d $\left(\mathrm{CH}_{2}\right)_{5} \mathrm{Tyr}(\mathrm{Me}) \mathrm{AVP}, \mathrm{d}\left(\mathrm{CH}_{2}\right)_{5}\left[\mathrm{D}-\mathrm{Ile}^{2}, \mathrm{Ile}^{4}, \mathrm{Ala}^{9}-\right.$ $\left.\mathrm{NH}_{2}\right]$ AVP and [1-D $\left(\mathrm{CH}_{2}\right)_{5}, \mathrm{Tyr}(\mathrm{ME})_{2}, \mathrm{Thr}^{4}$,Tyr-NH2(9)] ornithine vasotocin were obtained from Peninsula Lab, San Carlos, CA, USA. Naloxone, cypoheptadine, atropine, 6-OH gallamine, fluperidol, phentolamine, propranolol, MK801, bicuculline, 5-amino valeric acid (5AVA), 3-aminoproyl phossphonic acid (3APPA). and the other chemicals were bought from Sigma Co., St. Louis, MO, USA.

\subsection{Surgery}

With Pellegrino L.J. rat brain atlas as reference, we used the stereotaxic apparatus (Jiangwan I-C, Shanghai, China) to implant a stainless steel guide cannula of $0.5 \mathrm{~mm}$ outer diameter into the right lateral ventricle (AP $0.3 \mathrm{~mm}, \mathrm{LR}$ $0.5 \mathrm{~mm}, \mathrm{H} 3.0 \mathrm{~mm}$ ) for icv under the pentobarbital sodium (35 mg/kg, intraperitoneal injection) anaesthesia. The guide cannula was fixed to the skull by dental acrylic. All operations were carried out in the aseptic condition and the animals were allowed to recover for at least 14 days after the surgery.

\subsection{Intraventricular Injection (ICv)}

On the day of experiment, a stainless steel needle with $0.3 \mathrm{~mm}$ diameter for icv was directly inserted into the guide cannula, with $1 \mathrm{~mm}$ beyond the tip of the latter. The 10 $\mathrm{ml}$ of antiserum or solution was injected into the lateral ventricle gently over $10 \mathrm{~min}$.

\subsection{Nociceptive Tests}

All animals were tested under the condition of free activity in the small cages $(30 \mathrm{~cm}$ in diameter, $25 \mathrm{~cm}$ in height) from 8:00 to 10:00 am. Depending on the 30-year experience of studying pain in our laboratory, we used the potassium iontophoresis inducing tail-flick served as pain stimulus. The small wet cotton with the potassium iontophoresis was set on the skin of the tail. The cotton was exposed to direct electrical current, and the anode led the potassium iontophoresis to permeate the skin of the tail. If the current was strong enough, the permeated potassium iontophoresis resulted in the animal feeling the pain stimulation. The intensity of current at the moment of the response was recorded as the pain threshold, which was expressed as mA (WQ-9E Pain Threshold Measurer, Shanghai, China). The duration between consecutive stimuli was $10 \mathrm{~min}$, and the pain stimulus was terminated at once when the rat showed response to this stimulus.

\subsection{Histological Verification}

At the end of the experiments, the rat was sacrificed under the high dose of pentobarbital sodium $(80 \mathrm{mg} / \mathrm{kg}$, intraperitoneal injection), and the histological location of icv was ascertained. The data were excluded from analysis if the positions were not accurate.

\subsection{Statistical Analysis}

All values were expressed as mean \pm standard error of the mean (SEM) and were analyzed between groups by analysis of variance (ANOVA) and $\chi^{2}$ test. $P<0.05$ was considered statistically significant.

\section{RESULTS}

\subsection{Effect of the Neuropeptide Receptor Antagonist on Pain Threshold Increase Induced by AVP (icv)}

Table 1 showed that $100 \mathrm{ng}$ AVP (icv) could increase the pain threshold from $0.52 \pm 0.03 \mathrm{~mA}$ to $0.77 \pm 0.04 \mathrm{~mA}$ $(P<0.001)$.

Although icv of $2 \mu \mathrm{g} \mathrm{d}\left(\mathrm{CH}_{2}\right)_{5} \mathrm{Tyr}(\mathrm{Me}) \mathrm{AVP}\left(\mathrm{V}_{1}\right.$ receptor antagonist), $2 \mu \mathrm{g} \mathrm{d}\left(\mathrm{CH}_{2}\right)_{5}\left[\mathrm{D}-\mathrm{Ile}^{2}, \mathrm{Ile}^{4}, \mathrm{Ala}^{9}-\mathrm{NH}_{2}\right] \mathrm{AVP}$ ( $\mathrm{V}_{2}$ receptor antagonist), $2 \mu \mathrm{g}\left[1-\mathrm{D}\left(\mathrm{CH}_{2}\right)_{5}, \mathrm{Tyr}(\mathrm{ME})_{2}, \mathrm{Thr}^{4}\right.$, Tyr-NH2(9)] ornithine vasotocin (oxytocin receptor antagonist) or $2 \mu \mathrm{g}$ naloxone (opiate receptor antagonist) decreased the pain threshold (all $p<0.01 \sim 0.001$ ), ventricular pretreatment with $\mathrm{V}_{1}$ receptor antagonist, $\mathrm{V}_{2}$ receptor antagonis, opiate receptor antagonist could reverse the antinociceptive effect induced by $100 \mathrm{ng}$ AVP administration (icv), and ventricular pretreatment with oxytocin receptor antagonist did not influence the antinociceptive effect induced by $100 \mathrm{ng}$ AVP administration (icv) (Table 1).

\subsection{Effect of the Neurotransmitter Receptor Antagonist on Pain Threshold Increase Induced by AVP (icv)}

Table 2 showed that icv of $2 \mu \mathrm{g}$ 5-HT receptor antagonist (cypoheptadine), $2 \mu \mathrm{g} \mathrm{M}$ receptor antagonist (atropine), $2 \mu \mathrm{g} \mathrm{N}$ receptor antagonist (6-OH gallamine), $2 \mu \mathrm{g}$ $\alpha$ receptor antagonist (phentolamine) or $2 \mu \mathrm{g} \beta$ receptor antagonist (propranolol) decreased the pain threshold (all $p<0.01 \sim 0.001$ ), but $i c v$ of $2 \mu \mathrm{g}$ dopamine receptor antagonist (fluperidol), $2 \mu \mathrm{g}$ N-methyl-D-aspartate (NMDA) receptor antagonist (MK801), $2 \mu \mathrm{g} \gamma$-aminobutyric acid $(\mathrm{GABA})_{\mathrm{a}}$ receptor antagonist (bicuculline), $2 \mu \mathrm{g} \mathrm{GABA}_{\mathrm{b}}$ receptor antagonist (5-amino valeric acid) or $2 \mu \mathrm{g} \mathrm{GABA}_{c}$ receptor antagonist (3-aminoproyl phossphonic acid) did not influence the pain threshold.

Pretreatment with either 5-HT receptor antagonist or M receptor antagonist (icv) could attenuate the antinociceptive 
Table 1. Effect of neuropeptide receptor antagonist (icv) on the pain threshold increase induced by the central AVP.

\begin{tabular}{|c|c|c|c|c|}
\hline Treatment & $\mathrm{n}$ & Before injection & After 1st injection & After 2nd injection \\
\hline$\overline{\mathrm{ACSF}}+\mathrm{ACSF}$ & 10 & $0.50 \pm 0.03$ & $0.51 \pm 0.02$ & $0.52 \pm 0.03$ \\
\hline $\mathrm{ACSF}+\mathrm{AVP}$ & 10 & $0.51 \pm 0.03$ & $0.52 \pm 0.04$ & $0.77 \pm 0.04^{111222 * * *}$ \\
\hline $\mathrm{V}_{1}$ receptor antagonist $+\mathrm{ACSF}$ & 10 & $0.49 \pm 0.03$ & $0.41 \pm 0.04^{1}$ & $0.46 \pm 0.04$ \\
\hline $\mathrm{V}_{1}$ receptor antagonist $+\mathrm{AVP}$ & 10 & $0.51 \pm 0.04$ & $0.40 \pm 0.03^{11000}$ & $0.49 \pm 0.04^{1112000}$ \\
\hline $\mathrm{V}_{2}$ receptor antagonist $+\mathrm{ACSF}$ & 10 & $0.51 \pm 0.03$ & $0.41 \pm 0.02^{111 * *}$ & $0.43 \pm 0.03^{11} *$ \\
\hline $\mathrm{V}_{2}$ receptor antagonist $+\mathrm{AVP}$ & 10 & $0.50 \pm 0.02$ & $0.40 \pm 0.02^{111} \circ 00$ & $0.45 \pm 0.02^{1000}$ \\
\hline OXT receptor antagonist $+\mathrm{ACSF}$ & 9 & $0.49 \pm 0.03$ & $0.39 \pm 0.03^{11} * * *$ & $0.41 \pm 0.04^{1} * *$ \\
\hline $\mathrm{OXT}$ receptor antagonist $+\mathrm{AVP}$ & 9 & $0.51 \pm 0.03$ & $0.40 \pm 0.03^{111} \circ 00$ & $0.74 \pm 0.04^{11222 \text { aаa }}$ \\
\hline Opiate receptor antagonist $+\mathrm{ACSF}$ & 10 & $0.54 \pm 0.04$ & $0.37 \pm 0.01^{111} * * *$ & $0.35 \pm 0.03^{111} * * *$ \\
\hline Opiate receptor antagonist + AVP & 10 & $0.50 \pm 0.02$ & $0.34 \pm 0.03^{111 ~ \circ 0 \circ}$ & $0.62 \pm 0.03^{11222 \text { ○о० аaа }}$ \\
\hline
\end{tabular}

ACSF, $10 \mu \mathrm{l}$ artificial cerebrospinal fluid; AVP, $100 \mathrm{ng}$ arginine vasopressin; $\mathrm{V}_{1}$ receptor antagonist, $2 \mu \mathrm{g}\left(\mathrm{CH}_{2}\right)_{5} \mathrm{Tyr}(\mathrm{Me}) \mathrm{AVP} ; \mathrm{V}_{2}$ receptor antagonist, $2 \mu \mathrm{g}$ $\mathrm{d}\left(\mathrm{CH}_{2}\right)_{5}\left[\mathrm{D}-\mathrm{Ile}^{2}, \mathrm{Ile}^{4}, \mathrm{Ala}^{9}-\mathrm{NH}_{2}\right] \mathrm{AVP}$; OXT (oxytocin) receptor antagonist, $2 \mu \mathrm{g}\left[1-\mathrm{D}\left(\mathrm{CH}_{2}\right)_{5}, \mathrm{Tyr}(\mathrm{ME})_{2}, \mathrm{Thr}^{4}, \mathrm{Tyr}-\mathrm{NH} 2(9)\right]$ ornithine vasotocin; Opiate receptor antagonist, $2 \mu \mathrm{g}$ naloxone. All values are expressed as mean \pm standard error of the mean (SEM). The unit was $\mathrm{mA}$. N indicates the animal number of the group. Before injection denotes the animal before the treatment; First injection denotes the animal given first intraventricular injection (icv) of ACSF or receptor antagonist; Second injection denotes the animal given second icv of ACSF or AVP in $10 \mathrm{~min}$ after first injection. $P<0.05, * * P<0.01$ and $* * * P<0.001$ are for the comparison of the pain threshold from marked group and ACSF + ACSF group; ${ }^{\circ} P<0.05,{ }^{\circ} P<0.01$ and ${ }^{\circ 00} P<0.001$ are for the comparison of the pain threshold from marked group and ACSF + AVP group; ${ }^{1} P<0.05,{ }^{11} P<0.01$ and ${ }^{111} P<0.001$ are for the comparison of the pain threshold from marked value and the value before injection; ${ }^{2} P<0.05,{ }^{22} P<0.01$ and ${ }^{222} P<0.001$ are for the comparison of the pain threshold from marked value after $1^{\text {st }}$ injection and the value after $2^{\text {nd }}$ injection; ${ }^{\text {aaa }} P<0.001$ is for the comparison of the pain threshold from receptor antagonist + AVP group and receptor antagonist + ACSF group (corresponding control group).

Table 2. Effect of classical neurotransmitter receptor antagonists (icv) on the pain threshold increase induced by the central AVP.

\begin{tabular}{|c|c|c|c|c|}
\hline Treatment & $\mathrm{n}$ & Before injection & After 1st injection & After 2nd injection \\
\hline $\mathrm{ACSF}+\mathrm{ACSF}$ & 10 & $0.50 \pm 0.03$ & $0.51 \pm 0.02$ & $0.52 \pm 0.03$ \\
\hline $\mathrm{ACSF}+\mathrm{AVP}$ & 10 & $0.51 \pm 0.03$ & $0.52 \pm 0.04$ & $0.77 \pm 0.04^{111222} * * *$ \\
\hline 5-HT receptor antagonist $+\mathrm{ACSF}$ & 10 & $0.52 \pm 0.03$ & $0.27 \pm 0.02^{111} * * *$ & $0.23 \pm 0.01^{111 * * *}$ \\
\hline 5-HT receptor antagonist $+\mathrm{AVP}$ & 10 & $0.47 \pm 0.03$ & $0.30 \pm 0.03^{111 ~ \circ \circ \circ}$ & $0.31 \pm 0.05^{111 ~ \circ ० \circ}$ \\
\hline $\mathrm{M}$ receptor antagonist $+\mathrm{ACSF}$ & 9 & $0.50 \pm 0.03$ & $0.30 \pm 0.02^{111} * * *$ & $0.29 \pm 0.02^{111 * * *}$ \\
\hline $\mathrm{M}$ receptor antagonist $+\mathrm{AVP}$ & 9 & $0.51 \pm 0.03$ & $0.33 \pm 0.02^{111 ~ \circ 0 \circ}$ & $0.60 \pm 0.04^{111222 \text { о०० aаa }}$ \\
\hline $\mathrm{N}$ receptor antagonist $+\mathrm{ACSF}$ & 9 & $0.48 \pm 0.03$ & $0.47 \pm 0.03$ & $0.49 \pm 0.03$ \\
\hline $\mathrm{N}$ receptor antagonist $+\mathrm{AVP}$ & 9 & $0.49 \pm 0.03$ & $0.50 \pm 0.04$ & $0.84 \pm 0.06^{111222 \text { aаa }}$ \\
\hline DA receptor antagonist $+\mathrm{ACSF}$ & 9 & $0.52 \pm 0.03$ & $0.52 \pm 0.04$ & $0.51 \pm 0.03$ \\
\hline $\mathrm{DA}$ receptor antagonist $+\mathrm{AVP}$ & 9 & $0.52 \pm 0.03$ & $0.51 \pm 0.03$ & $0.82 \pm 0.05^{111222 \text { aаa }}$ \\
\hline$\alpha$ receptor antagonist $+\mathrm{ACSF}$ & 9 & $0.48 \pm 0.03$ & $0.38 \pm 0.03^{1 * * *}$ & $0.33 \pm 0.04^{11 * * *}$ \\
\hline$\alpha$ receptor antagonist $+\mathrm{AVP}$ & 9 & $0.49 \pm 0.03$ & $0.37 \pm 0.03^{1000}$ & $0.81 \pm 0.06^{111222 \text { aаa }}$ \\
\hline$\beta$ receptor antagonist $+\mathrm{ACSF}$ & 9 & $0.47 \pm 0.04$ & $0.38 \pm 0.03^{1 * * *}$ & $0.36 \pm 0.04^{1 * * *}$ \\
\hline$\beta$ receptor antagonist $+\mathrm{AVP}$ & 9 & $0.48 \pm 0.03$ & $0.39 \pm 0.03^{11 \circ \circ \circ}$ & $0.78 \pm 0.05^{111222 \text { aаa }}$ \\
\hline NMDA receptor antagonist $+\mathrm{ACSF}$ & 8 & $0.51 \pm 0.03$ & $0.49 \pm 0.04$ & $0.50 \pm 0.03$ \\
\hline NMDA receptor antagonist $+\mathrm{AVP}$ & 8 & $0.50 \pm 0.03$ & $0.48 \pm 0.03$ & $0.76 \pm 0.05^{111222 \text { aаa }}$ \\
\hline $\mathrm{GABA}_{\mathrm{a}}$ receptor antagonist $+\mathrm{ACSF}$ & 9 & $0.52 \pm 0.03$ & $0.49 \pm 0.03$ & $0.48 \pm 0.04$ \\
\hline $\mathrm{GABA}_{\mathrm{a}}$ receptor antagonist $+\mathrm{AVP}$ & 9 & $0.50 \pm 0.04$ & $0.52 \pm 0.03$ & $0.82 \pm 0.05^{111222 \text { aаa }}$ \\
\hline $\mathrm{GABA}_{b}$ receptor antagonist $+\mathrm{ACSF}$ & 9 & $0.48 \pm 0.03$ & $0.50 \pm 0.04$ & $0.47 \pm 0.04$ \\
\hline $\mathrm{GABA}_{\mathrm{b}}$ receptor antagonist $+\mathrm{AVP}$ & 9 & $0.50 \pm 0.04$ & $0.49 \pm 0.03$ & $0.79 \pm 0.05^{111222 \text { aаa }}$ \\
\hline $\mathrm{GABA}_{\mathrm{c}}$ receptor antagonist $+\mathrm{ACSF}$ & 9 & $0.51 \pm 0.03$ & $0.50 \pm 0.03$ & $0.47 \pm 0.04$ \\
\hline $\mathrm{GABA}_{\mathrm{c}}$ receptor antagonist $+\mathrm{AVP}$ & 9 & $0.50 \pm 0.04$ & $0.52 \pm 0.03$ & $0.83 \pm 0.05^{111222 \text { aaa }}$ \\
\hline
\end{tabular}

ACSF, $10 \mu \mathrm{l}$ artificial cerebrospinal fluid; AVP, $100 \mathrm{ng}$ arginine vasopressin; 5-HT (serotonin) receptor antagonist, $2 \mu \mathrm{g}$ cypoheptadine; M receptor antagonist, $2 \mu \mathrm{g}$ atropine; $\mathrm{N}$ receptor antagonist, $2 \mu \mathrm{g}$ 6-OH gallamine; DA (dopamine) receptor antagonist, $2 \mu \mathrm{g}$ fluperidol; $\alpha$ receptor antagonist: $2 \mu \mathrm{g}$ phentolamine; $\beta$ receptor antagonist: $2 \mu \mathrm{g}$ propranolol; NMDA (N-methyl-D-aspartate) receptor antagonist: $2 \mu \mathrm{g}$ MK801; GABAa ( $\gamma$-aminobutyric acid) receptor antagonist: 2 $\mu \mathrm{g}$ bicuculline; GABAb receptor antagonist: $2 \mu \mathrm{g}$ 5-amino valeric acid (5AVA); GABAc receptor antagonist, $2 \mu \mathrm{g}$ 3-aminoproyl phossphonic acid (3APPA). All values are expressed as mean \pm standard error of the mean (SEM). The unit was $\mathrm{mA}$. $\mathrm{N}$ indicates the animal number of the group. Before injection denotes the animal before the treatment; First injection denotes the animal given first intraventricular injection (icv) of ACSF or receptor antagonist; Second injection denotes the animal given second $i c v$ of ACSF or AVP in 10 min after first injection. $P<0.05, * * P<0.01$ and $* * * P<0.001$ are for the comparison of the pain threshold from marked group and ACSF + ACSF group; ${ }^{\circ} P<0.05,{ }^{\circ} P<0.01$ and ${ }^{\circ 0 \circ} P<0.001$ are for the comparison of the pain threshold from marked group and ACSF + AVP group; ${ }^{1} P<0.05,{ }^{11} P<0.01$ and ${ }^{111} P<0.001$ are for the comparison of the pain threshold from marked value and the value before injection; ${ }^{2} P<0.05,{ }^{22} P<0.01$ and ${ }^{222} P<0.001$ are for the comparison of the pain threshold from marked value after $1^{\text {st }}$ injection and the value after $2^{\text {nd }}$ injection; ${ }^{\text {aaa }} P<0.001$ is for the comparison of the pain threshold from receptor antagonist + AVP group and receptor antagonist + ACSF group (corresponding control group). 
effect induced by $100 \mathrm{ng}$ AVP administration (icv) (all $P$ $<0.001$ ), but the other studied neurotransmitter recaptor antagonists did not influence the antinociceptive effect induced by the administration of $100 \mathrm{ng}$ AVP (icv) (Table 2).

\section{DISCUSSION}

AVP is synthesized within cells located in the brain and in certain peripheral organs of the body. In the brain, AVP is synthesized in cell groups within the hypothalamus; several of these cell groups release hormones into the systemic circulation or into the portal circulation of the anterior pituitary gland and others release neurotransmitters at synaptic targets within the brain. AVP is also synthesized in certain extrahypothalamic brain sites, such as limbic system structures in the forebrain. In peripheral tissues, there is evidence that AVP is synthesized in the anterior pituitary, adrenal, and thymus glands and in male and female reproductive structures (ovaries, uterus, and testes) [3]. However, most of AVP is synthesized in hypothalamic paraventricular nucleus (PVN) and hypothalamic supraoptic nucleus (SON) [2,15]. It has been proven that PVN and SON play an important role in analgesia [16-20], and AVP, which may be from PVN and SON, is involved in pain modulation [21,22].

Our present study showed that (1) not only $\mathrm{V}_{1}$ receptor antagonist $\left[\mathrm{d}\left(\mathrm{CH}_{2}\right)_{5} \mathrm{Tyr}(\mathrm{Me}) \mathrm{AVP}\right]$ and $\mathrm{V}_{2}$ receptor antagonist $\left[\mathrm{d}\left(\mathrm{CH}_{2}\right)_{5}\left[\mathrm{D}-\mathrm{Ile}^{2}, \mathrm{Ile}^{4}, \mathrm{Ala}^{9}-\mathrm{NH}_{2}\right] \mathrm{AVP}\right]$ blocked the antinociceptive effect induced by AVP (icv), but also the opiate receptor antagonist (naloxone), 5-HT receptor antagonist (cypoheptadine) and $\mathrm{M}$ receptor antagonist (atropine) could reserve the antinociceptive effect induced by AVP (icv); (2) oxytocin, dopamine, NMDA, GABA, N, $\alpha$ and $\beta$ receptor antagonist did not influence the antinociceptive effect induced by AVP (icv). The data suggested that AVP antinociceptive effect was related with the endogenous opiate peptide, serotonin and acerycholine systems.

Histological study has shown that there are many AVP containing fibers in the periaqueductal gray (PAG), which come from PVN neurons [23,24]. AVP enhances the synthesis and secretion of endogenous opiate peptides in the PAG $[25,26]$.

The nucleus raphe magnus (NRM) is a serotonergic nucleus located in the rostral ventromedial medulla of the brainstem. Axons of the NRM project to the spinal cord [27], terminating primarily in the dorsal horn [28]. Brainstem nuclei that project to the dorsal horn of the spinal cord can function to inhibit afferent nociceptive transmission [29-31]. Activation of these descending antinociceptive pathways may be triggered by physiological stimuli [32] as well as by pharmacological agents [33]. Antinociception involving the NRM has been studied after either electrical stimulation or direct administration of pharmacological agents [34-36]. The NRM is a key neural structure for pain modulation, in which serotonin $(5-\mathrm{HT})$ is a major site for pain regulation [10]. AVP and 5-HT interaction in the brain controls many animal behaviors [37,38].

There are many bioactive substances in the caudate nucleus $(\mathrm{CdN})$ including dopamine (DA) and acetylcholine (Ach), which show interaction with AVP [35,39-41]. $\mathrm{DA}$ and Ach in $\mathrm{CdN}$ are important bioactive substances in pain modulation and the $\mathrm{CdN}$ is showing an important neural structure in pain modulation [38].

Our pervious study has shown that AVP in the PAG, NRM and CdN could regulate the pain process $[18,42,43]$, and pain stimulation changes the AVP concentration in the PAG, NRM and CdN $[15,40]$. So we could imagine that AVP regulating the pain process might be involved in the endogenous opiate system in the PAG, serotonin system in the NRM and acetylcholine system in the CdN. However, it needs to be confirmed.

\section{ACKNOWLEDGEMENTS}

This work was supported by Xinxiang Medical University, 101 Hospital of PLA, Jiangsu Su Bei People's Hospital and grants from National Basic Research Program of China (2007CB936104).

\section{REFERENCES}

[1] Aziz, H., Pearce, J. and Miller, E. (1968) Vasopressin in prevention of lumbar puncture headache. British Medical Journal, 4, 677-678. doi:10.1136/bmj.4.5632.677

[2] Martin, J.B., Reichlan, S. and Bick, K.L. (1981) Neurosecretion and brain peptides. Raven Press, New York.

[3] McEwen, B.B. (2004) The role of vasopressin and oxytocin in memory processing. Elsevier, Amsterdam.

[4] Berkowitz, B.A. and Sherman, S. (1982) Characterization of vasopressin analgesia. Journal of Pharmacology and Experimental Therapeutics, 220, 329-334.

[5] Berson, B.S., Berntson, G.G., Zipf, W., Torello, M.W. and Kirk, W.T. (1983) Vasopressin-induced antinociception: An investigation into its physiological and hormonal basis. Endocrinology, 113, 337-343. doi:10.1210/endo-113-1-337

[6] Kendler, K.S., Weitzman, R.E. and Fisher, D.A. (1978) The effect of pain on plasma arginine vasopressin concentrations in man. Clinical Endocrinology (Oxf), 8, 8994. doi:10.1111/j.1365-2265.1978.tb02156.x

[7] Madrazo, I., Franco-Bourland, R.E., Leon-Meza, V.M. and Mena, I. (1987) Intraventricular somatostatin-14, arginine vasopressin, and oxytocin: analgesic effect in a patient with intractable cancer pain. Applied Neurophysiology, 50, 427-431.

[8] Yang, J., Song, C.Y., Liu, W.Y. and Lin, B.C. (2006) Only through the brain nuclei, arginine vasopressin regulates antinociception in the rat. Peptides, 27, 3341-3346. doi:10.1016/j.peptides.2006.08.019

[9] Yang, J., Yang, Y., Wang, C.H., Wang, G., Xu, H.T., Liu, W.Y. and Lin, B.C. (2009) Effect of arginine vasopressin 
on acupuncture analgesia in the rat. Peptides, 30, 241247. doi:10.1016/j.peptides.2008.10.013

[10] Weng, N.Q. (1988) Pain and analgesia. Shanghai Science Press, Shanghai.

[11] Yang, J. (1994) Intrathecal administration of oxytocin induces analgesia in low back pain involving the endogenous opiate peptide system. Spine, 19, 867-871. doi:10.1097/00007632-199404150-00001

[12] Yang, J., Yang, Y., Chen, J.M., Liu, W.Y., Wang, C.H. and Lin, B.C. (2007) Central oxytocin enhances antinociception in the rat. Peptides, 28, 1113-1119. doi:10.1016/j.peptides.2007.03.003

[13] Yang, J., Yang, Y., Chen, J.M., Liu, W.Y., Wang, C.H. and Lin, B.C. (2007) Effect of oxytocin on acupuncture analgesia in the rat. Neuropeptides, 41, 285-292. doi:10.1016/j.npep.2007.05.004

[14] Zimmermann, M. (1983) Ethical guidelines for investigations of experimental pain in conscious animal. Pain, 16, 109-110. doi:10.1016/0304-3959(83)90201-4

[15] Dorner, G. and Kawakamin, M. (1978) Hormones and brain development. Elsevier, Amsterdam.

[16] Yang, J. and Lin, B.C. (1992) Hypothalamic paraventricular nucleus plays a role in acupuncture analgesia through the central nervous system in the rat. Acupuncture Electro-Therapeutics Research, 17, 209-220.

[17] Shiraishi, T., Onoe, M., Kojima, T., Sameshima, Y. and Kageyama, T. (1995) Effects of hypothalamic paraventricular nucleus: Electrical stimulation produce marked nalgesia in rats. Neurobiology (Bp), 3, 393-403.

[18] Yang, J., Chen, J.M., Liu, W.Y., Song, C.Y. and Lin, B.C. (2008) Investigating the role of hypothalamic paraventricular nucleus in nociception of the rat. International Journal of Neuroscience, 118, 473-485. doi:10.1080/00207450601123563

[19] Yang, J., Yang, Y., Chen, J.M., Liu, W.Y., Wang, C.H. and Lin, B.C. (2008) Effect of hypothalamic supraoptic nucleus on acupuncture analgesia in the rat. Brain Research Bull, 75, 681-686. doi:10.1016/j.brainresbull.2007.11.004

[20] Yang, J., Yang, Y., Chen, J.M., Liu, W.Y., Wang, C.H. and Lin, B.C. (2008) Investigating the role of the hypothalamic supraoptic nucleus in nociception in the rat. Life Science, 82, 166-173. doi:10.1016/j.lfs.2007.10.023

[21] Bodnar, R.J., Nilaver, G., Wallace, M.M., Badillo-Martinez, D. and Zimmerman, E.A. (1984) Pain threshold changes in rats following central injection of beta-endorphin, met-enkephalin, vasopressin or oxytocin antisera. International Journal of Neuroscience, 24, 149-160. doi: 10.3109/00207458409089803

[22] Yang, J., Yang, Y., Chen, J.M., Xu, H.T., Liu, W.Y., Wang, C.H. and Lin, B.C. (2007) Arginine vasopressin is an important regulator in antinociceptive modulation of hypothalamic paraventricular nucleus in the rat. Neuropeptides, 41, 165-176. doi:10.1016/i.npep.2006.12.005

[23] Antunes, J.L. and Zimmerman, E.A. (1978) The hypothalamic magnocellular system of the rhesus monkey: An immunocytochemical study. Journal of Comparative Neurology, 81, 539-565. doi:10.1002/cne.901810306

[24] Swanson, L.W. and Sawchenko, P.E. (1980) Separate neurons in the paraventricular nucleus project to the median eminence and to the medulla or spinal cord. Brain Research, 198, 190-195. doi:10.1016/0006-8993(80)90354-6

[25] Yang, J., Yang, Y., Xu, H.T., Chen, J.M., Liu, W.Y. and Lin, B.C. (2006) Arginine vasopressin enhances periaqueductal grey synthesis and secretion of enkephalin and endorphin in the rat. Brain Research Bull, 71, 193-199. doi:10.1016/j.brainresbull.2006.09.003

[26] Yang, J., Yang, Y., Chen, J.M., Xu, H.T., Liu, W.Y. and Lin, B.C. (2007) Arginine vasopressin in periaqueductal gray, which relates to antinociception, comes from hypothalamic paraventricular nucleus in the rat. Neuroscience Letters, 412, 154-158. doi:10.1016/j.neulet.2006.10.049

[27] Bowker, R.M., Westlund, K.N., Sullivan, M.C. and Coulter, J.D. (1982) Organization of descending serotonergic projections to the spinal cord. Prog Brain Research, 57, 239-265. doi:10.1016/S0079-6123(08)64132-1

[28] Jones, S.L. and Light, A.R. (1990) Electrical stimulation in the medullary nucleus raphe magnus inhibits noxious heat-evoked protein-like immunoreactivity in the rat lumbar spinal cord. Brain Research, 530, 335-538. doi:10.1016/0006-8993(90)91306-2

[29] Basbaum, A.I. and Fields, H.L. (1979) The origin of descending pathways in the dorsolateral funiculus of the spinal cord of the cat and rat: Further studies on the anatomy of pain modulation. Journal of Comparative Neurology, 187, 513-532. doi:10.1002/cne.901870304

[30] Fields, H.L. and Besson, J.M. (1988) Progress in brain research, Pain modulation. Elsevier, Amsterdam, 77.

[31] Sandkuhler, J. (1996) The organization and function of endogenous antinociceptive systems. Prog Neurobiology, 50, 49-81. doi:10.1016/0301-0082(96)00031-7

[32] Myers, R.D., Rezvani, A.H. and Gurley-Orkin, L.A. (1985) New doublelumen polyethylene cannula for push-pull perfusion of brain tissue in vivo. Journal of Neuroscience Methods, 12, 205-218. doi:10.1016/0165-0270(85)90003-2

[33] Gogas, K.R., Presley, R.W., Levine, J.D. and Basbaum, A.I. (1991) The antinociceptive action of supraspinal opioids results from an increase in descending inhibitory control: Correlation of nociceptive behavior and c-fos expression. Neuroscience, 42, 617-628. doi:10.1016/0306-4522(91)90031-I

[34] Proudfit, H.K. and Anderson, E.G. (1975) Morphine analgesia: Blockade by raphe magnus lesions. Brain Research, 98, 612-618. doi:10.1016/0006-8993(75)90380-7

[35] Newman, M.E. (1985) Vasopressin inhibits cyclic AMP accumulation and adenylate activity cerebral preparation. FEBS Letters, 181, 203-206. doi:10.1016/0014-5793(85)80260-X

[36] Brodie, M.S. and Proudfit, H.K. (1986) Antinociception induced by local injections of carbachol into the nucleus raphe magnus in rats: Alteration by intrathecal injection of monoaminergic antagonists. Brain Research, 371, 70-79. doi:10.1016/0006-8993(86)90811-5

[37] Albers, H.E., Karom, M. and Smith, D. (2002) Serotonin and vasopressin interact in the hypothalamus to control communicative behavior. NeuroReport, 13, 931-933. doi:10.1097/00001756-200205240-00006

[38] Ferris, C.F. and Delville, Y. (1994) Vasopressin and serotonin interactions in the control of agonistic behavior. Psychoneuroendocrinology, 19, 593-601. 
doi:10.1016/0306-4530(94)90043-4

[39] Yang, J., Chen, J.M., Liu, W.Y., Song, C.Y. and Lin, B.C. (2006) Arginine vasopressin in the caudate nucleus plays an antinociceptive role in the rat. Life Science, 79, 2086-2090. doi:10.1016/j.lfs.2006.07.005

[40] Courtney, N. and Raskind, M. (1983) Vasopressin affects adenylate cyclase activity in rat brain: A possible neuromodulator. Life Science, 7, 591-596. doi:10.1016/0024-3205(83)90203-5

[41] Pefracca, F.M., Baskin, D.G., Diaz, J. and Dorsa, O.M. (1986) Ontogenetic changes in vasopressin binding site distribution in rat brain: An autoradiographic study. Brain Research, 393, 63-68.

[42] Yang, J., Chen, J.M., Liu, W.Y., Song, C.Y., Lin, B.C. (2006) Effect of arginine vasopressin in the nucleus raphe magnus on antinociception in the rat. Peptides, 27, 2224-2229.

[43] Yang, J., Chen, J.M., Liu, W.Y., Song, C.Y., Lin, B.C. (2006) Through V2, not V1 receptor relating to endogenous opiate peptides, arginine vasopressin in periaqueductal gray regulates antinociception in the rat. Regulatory Peptides, 137, 156-161. 